DOI: https://doi.org/10.24127/ajpm.v9i3.2790

\title{
EFEK PEMBELAJARAN TAMBAHAN MENGGUNAKAN SCHOOLOGY PADA MATA KULIAH KALKULUS
}

\author{
Sufri Mashuri ${ }^{1}$, Akbar Nasrum ${ }^{2 *}$ \\ ${ }^{1,2}$ Pendidikan Matematika, Universitas Sembilanbelas November Kolaka, Indonesia \\ *Corresponding author. Jl. Pemuda, Tahoa, Kolaka, Kabupaten Kolaka, Sulawesi Tenggara 93561 \\ E-mail: $\quad$ sufrimashuri@gmail.com ${ }^{1)}$ \\ $\underline{\text { akbar.nasrum@gmail.com }}^{2 *)}$
}

Received 02 May 2020; Received in revised form 07 September 2020; Accepted 14 September 2020

\begin{abstract}
Abstrak
Tujuan dari penelitian ini adalah ingin melihat efek dari pemberian pembelajaran tambahan terdahap pemahaman materi Kalkulus. Selain itu juga ingin melihat kemampuan Schoology dalam hal pengelolaan kelas online, baik dalam diskusi, kemampuan berkirim pesan, pemberian materi, tugas dan lain sebagainya. Penelitian ini merupakan penelitian eksperimen dengan model desain post test only control group design. Untuk menguji efek yang dihasilkan dari pembelajaran tambahan menggunakan Schoology, diambil dua kelompok kelas mahasiswa pendidikan matematika Angkatan 2017 Universitas Sembilanbelas November Kolaka yang mempunyai kemampuan relatif sama dan homogen, kemudian masing-masing diuji menggunakan aplikasi Schoology. Data yang diperoleh dari hasil ujian dianalisis menggunakan statistik deskriftip dan inferensial. Mahasiswa yang mendapat pembelajaran tambahan mempunyai pemahaman konsep materi yang lebih baik dibandingkan mahasiwa yang tidak mendapat pembelajaran tambahan. Selisih rataan pemahaman konsep mereka sebesar 31,89. Hasil inferensi statistik membuktikan bahwa perbedaan tersebut sangat signifikan. Oleh karena itu disimpulkan bahwa pemberian tambahan belajar bagi mahasiswa pada materi Kalkulus dapat meningkatkan pemahaman materi bagi mereka. Selain itu, Schoology yang merupakan sosial medianya para pelajar dapat meningkatkan motivasi belajar mahasiswa. Dengan meningkatnya motivasi belajar, proses belajar menjadi lebih efektif sehingga implikasi terhadap pemahaman materi menjadi lebih baik.
\end{abstract}

Kata kunci: Kalkulus; Schoology.

\begin{abstract}
The purpose of this study is to look at the effects of providing additional learning in an understanding of Calculus material. It also wants to see the ability of Schoology in terms of online classroom management, both in discussions, the ability to send messages, giving materials, assignments, and others. This research is an experimental study with a post-test only control group design. To test the effects resulting from additional learning using Schoology, two groups of Class 2017 Mathematics education students at the Nineteen November University Kolaka, who had relatively the same and homogeneous abilities, were taken. Each was tested using the Schoology application. Data obtained from the test results were analyzed using descriptive and inferential statistics. Students who receive additional learning have a better understanding of the concept of material than students who do not receive further knowledge. The difference between their mean understanding of the idea was 31.89. The statistical inference results prove that this difference is very significant. Therefore it is concluded that providing additional learning for students in calculus material can improve their understanding of the material. Besides, Schoology, which is social media for students, can increase student motivation to learn. With an increased motivation to learn, the learning process becomes more effective so that the implications for understanding the material are better.
\end{abstract}

Keywords: Calculus; Schoology.

This is an open access article under the Creative Commons Attribution 4.0 International License 
DOI: https://doi.org/10.24127/ajpm.v9i3.2790

\section{PENDAHULUAN}

Kalkulus merupakan mata kuliah esensial dalam bidang matematika ataupun pendidikan matematika. Pada perguruan tinggi, mata kuliah ini diberikan di semester awal karena mendasari beberapa mata kuliah lain seperti Kalkulus Multivariabel dan analisis real. Pemahaman materi dasar yang kurang maksimal akan memberikan dampak negatif terhadap hasil belajar pada mata kuliah lanjut yang membutuhkan dasar-dasar Kalulus. Materi dasar dalam Kalkulus yang dibahas di semester awal cukup banyak sehingga butuh banyak waktu untuk memahami semua materi yang ada di dalamnya. Penjelasan materi yang diperoleh dalam ruang kuliah tidak dapat memberikan jaminan pemahaman materi secara utuh karena ketersediaan waktu yang terbatas. Oleh karena itu dibutuhkan pembelajaran tambahan sebagai upaya untuk memahami materi Kalkulus secara maksimal. Kesediaan guru/dosen dalam meluangkan waktu memberikan pelajaran tambahan sangat membantu peserta didik dalam memahami materi pelajaran (Saputri \& Rahmawati, 2019)

Ada beberapa alternatif yang dapat digunakan untuk memberikan pembelajaran tambahan yaitu tatap muka secara langsung, secara daring, maupun kombinasi antara keduanya (Blended Learning). Pembelajaran secara daring merupakan salah satu alternatif yang baik karena lebih fleksibel. Tidak memerlukan tempat tertentu dan dapat dilaksanakan kapan saja sesuai dengan kesepakatan antara dosen dan mahasiswa.

Saat ini sudah banyak tersedia platform pembelajaran online yang dapat digunakan untuk proses belajar mengajar jarak jauh seperti Moodle,
Edmodo, Google class room, Scholoogy dan lain-lain sebagainya. Berkembang pesatnya platform pembelajaran ini sebagai akibat dari revolusi industri 4.0.

Revolusi industri 4.0 memaksa kita semua yang bergelut dalam dunia pendidikan untuk mengikuti perkembangan pembelajaran. Agar mahasiswa dapat memahami materi Kalkulus secara maksimal, kami berencana untuk memberikan pembelajaran tambahan menggunakan media Schoology. Schoology dipilih karena kemudahan penggunaanya. Setiap pengguna facebook akan mudah mengoperasikan Schoology karena tampilan antar muka platform ini hampir sama dengan facebook (Aminoto \& Pathoni, 2014). Selain kemudahan dalam pengoperasian, pertimbangan lainnya adalah kemampuannya yang baik dalam manajemen pembelajaran. Dalam Schoology terdapat fitur absensi, kuis, tugas, ruang diskusi, folder tempat penyimpanan materi yang memudahkan dalam pengelolaan pembelajaran (Ulva et al., 2018). Berbagai macam fitur dalam Schoology dapat mendukung proses pembelajaran dengan baik. Terdapat fitur untuk berkomunikasi antara mahasiswa dengan dosen dan sesama mahasiswa. Dalam Schoology, bukan hanya mahasiswa yang bisa mendaftar melainkan orang tua mahasiswa juga bisa daftar untuk memantau perkembangan anaknya. Kerjasama dan komunikasi yang baik antara tutor, orang tua dan mahasiswa diharapkan dapat memberikan hasil yang maksimal.

Dengan menggunakan Schoology, kami dapat mengatur jadwal kursus online sesuai dengan yang diinginkan. Materi-materi dapat diupload ke dalam sistem dan dapat didistribusikan ke 
semua mahasiswa kapanpun kita inginkan. Oleh mahasiswa materi dapat diunduh kapan saja dan dimana saja karena Schoology dapat diakses menggunakan perangkat Handphone /Gadget (Bano et al., 2018). Model pembelajaran seperti ini juga termasuk dalam pembelajaran elearning mobile. Pembelajaran yang dapat diakses diluar kelas reguler (Crompton \& Burke, 2018).

Beberapa penelitian lain yang berkaitan dengan e-learning menyatakan bahwa Schoology sangat efektif digunakan dalam proses pembelajaran online. (Firmansyah, 2015) menyatakan bahwa Blended Learning berbasis Schoology dapat meningkatkan efektifitas dan fleksibilitas dalam pembelajaran dan meningkatkan kualitas pendidikan dalam bidang IPTEK. Penerapan e-learning berbasis Schoology memberikan pengaruh positif terhadap hasil belajar siswa (Kartika Murni, 2016). Pendapat yang sama dikemukakan oleh (Putri et al., 2014) menyatakan bahwa hasil belajar sebelum penggunaan media dan setelah menggunakan media Schoology mengalami peningkatan.

Media ini juga efektif digunakan untuk meningkatkan keterampilan berfikir kritis siswa (Ardianti et al., 2019). Selain itu penggunan Schoology juga dapat meningkatkan motivasi belajar siswa. karena kemudahan cara pakainya, tampilan yang ramah, dan cara yang menantang dalam mengerjakan tugas (Rosalina, 2018) dan dapat lebih memotivasi peserta didik dalam kegiatan pembelajaran (Purwaningsih et al., 2017). Pengembangan media pembelajaran seperti ini juga sudah teruji efektif dan dapat menghasilkan ketuntasan belajar di atas 85\% (Wahyudi, 2017). Namun pembelajaran ini tidak dapat berjalan tanpa adanya jaringan internet (Haryanto, 2018). Ini merupakan salah satu kekurangan dalam media pembelaran Schoology.

Banyak peneliti yang melakukan pengembangan pembelajaran menggunakan media Schoology namun hanya pada materi-materi tingkat SMP dan SMA. Untuk pengembangan pembelajaran di tingkat pendidikan tinggi masih sangat kurang khususnya pada mata kuliah Kalkulus. Selain itu indikator yang diukur kebanyakan menggunakan hasil belajar. Pengukuran indikator lain seperti pemahaman konsep terbilang masih sangat kurang. Tidak kalah penting penggunaan media daring Schoology di Universitas Sembilanbelas November Kolaka khususnya di Program Studi pendidikan Matematika belum pernah diterapkan.

Padahal LMS ini sudah lama dikenal dikalangan para pendidik di Indonesia. Koneksi jaringan lumayan baik dan hampir semua mahasiswa memiliki smartphone android yang dapat digunakan untuk melakukan proses pembelajaran online.

Oleh karena itu perlu dikembangkan proses pembelajaran tambahan menggunakan Schoology untuk mengetahui efek dari pembelajaran tambahan yang diberikan. Selain itu juga ingin diketahui efek dari penggunaan Schoology dalam belajar serta kendala yang ditemui saat melaksanakan pembelajaran online.

\section{METODE PENELITIAN}

Penelitian ini merupakan penelitian eksperimen menggunakan desain Post Test only Control Group Design. Sampel yang digunakan adalah sampel jenuh yaitu mahasiswa semester 5 program studi pendidikan matematika Universitas Sembilanbelas November Kolaka. Mahasiswa Angkatan 2017 ini 
hanya terdiri dari dua kelas. Kelas A terdiri dari 20 orang dan kelas B terdiri dari 22 orang. Penentuan kelas eksperimen dan kelas kontrol dilakukan dengan cara diundi. Berdasarkan hasil undian, kelas B ditetapkan sebagai kelas eksperimen yang dikenai perlakuan dan kelas A merupakan kelas kontrol.

Penelitian ini melalui tiga fase. Fase pertama adalah pemberian tambahan belajar pada kelas eksperimen. Media yang digunakan untuk fasilitas kursus online adalah Schoology yang bisa diakses setelah mendaftar ke sistem. Setelah terdaftar, mahasiswa bisa masuk ke sistem dan mengunduh semua bahan ajar yang sudah disediakan oleh pemilik kelas. Bahan ajar yang disediakan berupa video tutorial yang merupakan pengembangan berbentuk audiovisual (Nasrum \& Herlina, 2019). Video ini disematkan ke sistem Schoology sesuai jadwal kuliah online yang telah ditetapkan. Video tersebut berisi penjelasan materi disertai contoh dan soal latihan..

Untuk fase pertama terdiri dari beberapa tahapan yaitu:: (1) Daftar ke Schoology dengan kode kelas CRW72CVT-F79NR; (2) Log in ke sistem menggunakan email dan password yang telah dibuat; (3) Unduh semua materi yang tersedia dalam sistem dan pelajari; (4) Tanya ke tutor tentang materi atau penjelasan yang tidak dimengerti saat temu online.

Temu online dilakukan dua kali dalam seminggu. Setiap pertemuan menghabiskan waktu kurang lebih dua jam untuk membahas materi yang kurang dimengerti. Jika ada pertanyaan yang tidak terjawab dalam temu online akan dibahas kembali di dalam kelas.

Selanjutnya fase kedua adalah fase evaluasi. Proses evaluasi juga dilakukan menggunakan fasilitas yang ada dalam Schoology. Dua kelas mahasiswa matematika semester 5 jurusan pendidikan matematika Universitas Sembilanbelas November Kolaka diambil untuk mengukur pemahaman konsep Kalkulus mereka. Hasilnya tidak diperiksa secara manual melainkan melalui sistem itu sendiri. Instrumen soal dapat diatur sedemikian rupa sehingga menyerupai sistem soal pada Ujian Nasional atau ujian lain yang berbasis komputer.

Data yang diperoleh dalam tahapan ini kemudian dianalisa menggunakan menggunakan statistik deskriptif yang dilanjutkan dengan tahapan inferensi menggunakan statistik uji-t. Fase terakhir adalah tahap wawancara semi terstruktur yaitu jenis wawancara yang menggunakan beberapa poin kunci pertanyaan yang disiapkan sebelum wawancara dimulai. Selanjutnya pertanyaan tersebut bisa diperluas dengan memberikan kebebasan pada pewawancara.

\section{HASIL DAN PEMBAHASAN}

Seperti yang dijelaskan pada bab sebelumnya dalam teknis pelaksanaan kursus online pada langkah ke-3 mahasiswa dapat mengunduh file materi dalam bentuk video yang telah disediakan dalam sistem. File-file yang diupload ke dalam sistem tidak langsung ada begitu saja. Proses pembuatannya memakan banyak waktu mulai dari tahap persiapan materi sampai menghasilkan produk video (Nasrum \& Herlina, 2019). Adapun materi-materi yang sudah diaupload ke Schoology dapat dilihat pada Tabel 1.

Schoology biasa disebut sebagai media sosialnya para pelajar. Aplikasi ini memadukan Learning Management System dengan jejaring sosial. Selain dapat digunakan sebagai wadah dalam 
DOI: https://doi.org/10.24127/ajpm.v9i3.2790

mengatur pembelajaran dalam kelas dan juga berkomunikasi antar teman. Tabel 1. Daftar Materi yang ada dalam Kelas Kalkulus I pada Schoology

\begin{tabular}{|c|c|c|}
\hline No & Judul Materi & Link Video \\
\hline 1 & Definisi Fungsi & https://youtu.be/3ioFy61n2N4 \\
\hline 2 & Fungsi Linier 1 & https://youtu.be/qwskB0QOIko \\
\hline 3 & Fungsi Linier 2 & https://youtu.be/8V4-LFMCKZk \\
\hline 4 & Fungsi Kuadrat & https://youtu.be/YYIaubx6XUA \\
\hline 5 & Pergeseran Grafik & $\underline{\text { https://youtu.be/3AEtoTKig0s }}$ \\
\hline 6 & Nilai Mutlak & https://youtu.be/ZnKBvemAn1I \\
\hline 7 & Limit Secara Intuisi & https://youtu.be/hBFHTPEdi8U \\
\hline 8 & Limit Kiri dan Kanan & https://youtu.be/U0MFpTFhI8w \\
\hline 9 & Teorema-teorema Limit & https://youtu.be/yTf2qPN--IU \\
\hline 10 & Teorema Apit & $\underline{\text { https://youtu.be/KMkE78DuXPw }}$ \\
\hline 11 & Limit Presisi & $\underline{\text { https://youtu.be/aIn-pNVqJR0 }}$ \\
\hline 12 & Definisi Turunan & https://youtu.be/EyZ57HhrIK4 \\
\hline 13 & Uji Turunan 1 & https://youtu.be/CAXqitXkmLw \\
\hline 14 & Max dan Min & https://youtu.be/AZRxBvY4hDM \\
\hline
\end{tabular}

Keunggulannya dalam sistem pengaturan pembelajaran sudah tidak diragukan lagi. Beberapa fasilitas yang mendukung proses pembelajaran sudah tersedia dalam sistem. Perhatikan Gambar 1.
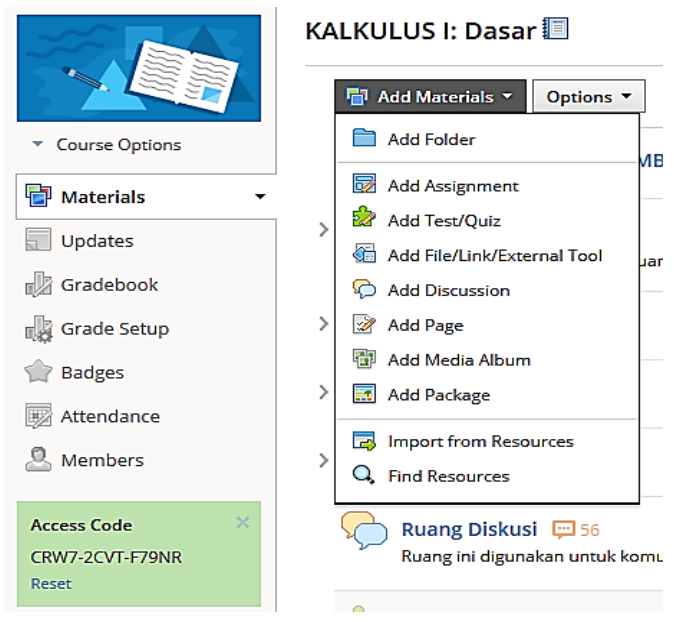

Gambar 1. Fasilitas yang ada pada Schoology
Dalam menu add material, kita dapat menambahkan folder melalui menu add folder dan mengunggah bahan ajar baik berupa video maupun file ke sistem. Bahan ajar yang sudah tersimpan dapat ditampilkan ke akun mahasiswa sesuai dengan keinginan pemilik kelas. Jadi, bahan ajar tidak bisa diunduh sebelum dipersilahkan oleh pemilik kelas. Untuk masalah penilaian (Assesment) kita dapat menggunakan fitur Add Assignment dan add test/quist. Dalam pembuatan soal tersedia beberapa pilihan seperti soal pilihan ganda, soal benar-salah, menjodohkan dan soal isian. Pembuatan soal matematika dalam shoology lebih mudah dibandingkan LMS yang lain karena tersedia fasilitas Lateks dan menu untuk simbol matematika. 
DOI: https://doi.org/10.24127/ajpm.v9i3.2790

Untuk membahas satu materi dalam pertemuan online, pemilik kelas dapat membuka ruang diskusi melalui menu add discussion. Ruang inilah yang digunakan untuk berkomunikasi dengan mahasiswa. Penggunaanya tidak jauh berbeda dengan media sosial lainnya. Fitur komunikasi ini dapat digunakan untuk bertukar file berupa gambar atau video (Perhatikan Gambar 2). Hanya saja proses pengiriman pesan tidak secepat jika dibandingkan dengan media sosial seperti Whatsapp.

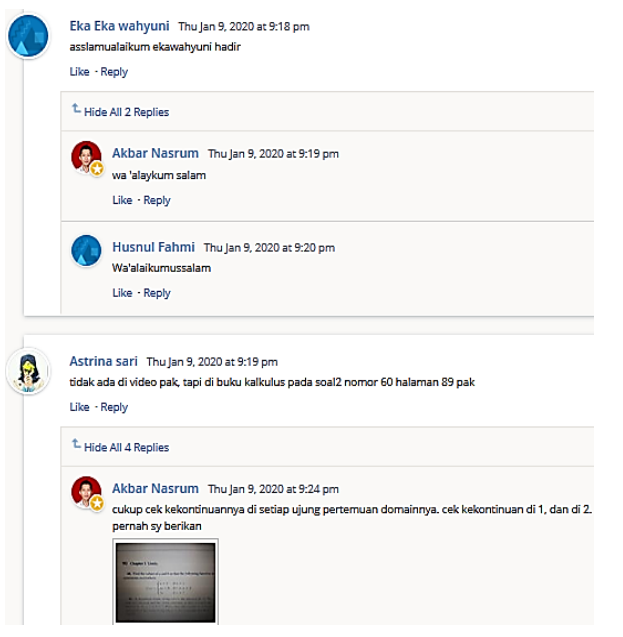

Gambar 2. Proses berkirim pesan via Schoology

Selain fasilitas itu, tersedia fasilitas absensi yang dapat digunakan untuk mengecek kehadiran mahasiswa dalam setiap pertemuan. Sayangnya, kita tidak dapat memantau apakah mereka tetap online dan mengikuti pelajaran atau tidak. Fitur yang dapat digunakan untuk memantau aktifitas mahasiswa selama online adalah fitur analitic dan fitur ini tidak ada dalam Schoology basic yang digunakan.

Selain mengulang materi yang ada di kelas, mahasiswa juga diberikan materi-materi pengayaan yang lebih detail. Materi Kalkulus berbentuk vidio yang disajikan dengan menggunakan alat bantu Geogebra membuat materi lebih mudah dipahami (Caligaris et al., 2015). Dengan adanya pembelajaran tambahan tentu saja pemahaman mahasiswa terhadap suatu materi menjadi lebih baik. Ini terlihat jelas dari hasil tes antara mahasiswa yang diberi pembelajaran tambahan dan yang tidak diberi pembelajaran tambahan.

Jika dilihat dari ukuran pemusatan data antara dua kelas yang diuji, nilai kelas B yaitu kelas yang mendapat pembelajaran tambahan menggunakan Schoology selalu lebih baik dari kelas A, baik dalam hal rata-rata, median maupun modusnya. Hal tersebut dapat dilihat pada Tabel 2 .

Tabel 2. Statistik deskriptif kedua kelas

\begin{tabular}{ccc}
\hline Statistik & A & B \\
\hline Rata-rata & 47,61 & 79,50 \\
Median & 46,00 & 77,00 \\
Modus & 60,00 & 100,00 \\
Standar Deviasi & 25,01 & 15,23 \\
\hline
\end{tabular}

Statistik ini didukung oleh hasil uji statistik perbandingan dua rataan yang dapat dilihat pada Tabel 3. Hasil uji-t pada Tabel 3 diperoleh nilai Sig. < $\alpha=0,05$. Dari hasil ini dapat disimpulkan bahwa perbedaan rataan antara dua kelas memang sangat signifikan. Kemampuan pemahaman konsep mahasiswa yang diberikan pembelajaran tambahan melalui Schoology jauh lebih baik dibandingkan dengan yang tidak mendapat pembelajaran tambahan. Dari sini terlihat bahwa pemberian pembelajaran tambahan memberikan efek positif terhadap pemahaman suatu materi. Pembelajaran tambahan juga membuat peserta didik lebih siap dalam belajar, 
DOI: https://doi.org/10.24127/ajpm.v9i3.2790

hal ini sesuai dengan yang dikemukakan oleh (Saputri \& Rahmawati, 2019).

Tabel 3. Hasil uji-t perbandingan dua rataan

\section{t-test for Equality of Means}

\begin{tabular}{cccc}
\hline $\mathrm{t}$ & $\mathrm{df}$ & $\begin{array}{c}\text { Sig. } \\
\text { (2-tailed) }\end{array}$ & $\begin{array}{c}\text { Mean } \\
\text { Differences }\end{array}$ \\
\hline 4,621 & 34 & 0,000 & 31,889 \\
\hline
\end{tabular}

Selain dari faktor pembelajaran tambahan, faktor penggunaan media juga turut memberikan pengaruh terhadap pemahaman materi mahasiswa. Penggunaan schoology dipercaya dapat meningkatkan motivasi belajar peserta didik sehingga memberikan pengaruh kepada pemahaman konsep suatu materi. Hal ini sejalan dengan penelitian (Purwaningsih et al., 2017) yang dalam penelitiannya menyimpulkan bahwa penggunaan media Schoology dapat lebih memotivasi peserta didik dalam kegiatan pembelajaran. Hal serupa juga disampaikan oleh (Rosalina, 2018) bahwa penggunan Schoology dapat meningkatkan motivasi belajar siswa. karena kemudahan cara pakainya, tampilan yang ramah, dan cara yang menantang dalam mengerjakan tugas

Dengan meningkatnya motivasi belajar, serta kemudahan dalam mengoperasikan media, pembelajaran akan menjadi lebih efektif seperti hasil penelitian yang diperoleh. Hal ini juga sesuai dengan hasil penelitian (Putri et al., 2014) yang menyimpulkan bahwa penggunaan Schoology sangat efektif digunakan dalam proses belajar mengajar.

Selanjutnya dari sisi penggunaan, ada beberapa kendala dalam melaksanakan pembelajaran online. Pertama, butuh waktu mempersiapkan materi yang akan disajikan dalam bentuk video tutorial. Sebaiknya materi dalam bentuk video dipersiapkan jauh sebelum mempersiapkan pembelajaran online karena pembuatan video pembelajaran butuhkan waktu yang tidak sedikit. Mulai dari persiapan materi, pembuatan slide, proses perekaman dan proses pengeditan butuh waktu yang cukup lama (Nasrum \& Herlina, 2019). Kedua, pembelajaran online butuh jaringan wifi atau jaringan seluler. Jaringan wifi dalam kampus kami masih sangat terbatas. Itupun hanya dapat diakses oleh dosen dan staf. Belum tersedia kuota tersendiri untuk para mahasiswa. Jalan satu-satunya adalah menggunakan jaringan seluler. Tentu saja butuh dana untuk membeli kuota/data dan kondisi ini tidak bisa dipaksakan ke mahasiswa. Ketiga, aplikasi schology kurang maksimal jika menggunakan Gadget/Handphone. Terkadang ada fitur yang tidak terlihat melalui layar kecil tersebut. Aplikasi ini akan berfungsi maksimal jika menggunakan laptop atau $P C$. Namun tidak semua mahasiswa memiliki laptop atau $P C$.

Jika seandainya jaringan wifi mendukung dan masing-masing mahasiswa punya laptop, maka aplikasi ini benar-benar menjadi solusi pembelajaran masa depan. Melalui aplikasi ini pembelajaran dapat dilakukan melalui teleconference.

Penelitian ini memberikan penguatan kepada mahasiswa bahwa untuk memperoleh hasil belajar yang maksimal, materi harus selalu diulangulang. Selain itu penelitian ini memberikan pengetahuan baru tentang proses belajar mengajar jarak jauh sehingga mahasiswa tidak kaku jika sewaktu-waktu proses belajar mengajar dengan sistem daring harus diterapkan. Hasil dari penelitian ini, mahasiswa tidak terlalu kaku lagi dalam pelaksanaan kuliah daring atau online 
yang diterapkan selama masa pandemi Covid-19.

\section{KESIMPULAN DAN SARAN}

Dari hasil penelitian dan pembahasan di atas dapat ditarik beberapa kesimpulan yaitu: Pertama, media Schoology sangat baik dan efektif digunakan untuk pembelajaran online. Efek dari tambahan pelajaran yang dilakukan menggunakan Schoology membuat pemahaman mahasiswa menjadi lebih baik. Sebaik apapun suatu sistem pasti memiliki kekurangan namun semua kekurangan bisa tertutupi dengan memberikan solusi yang tepat. Kelemahan Schoology dalam hal kecepatan transfer data saat temu online salah satunya diakibatkan oleh jaringan dan banyaknya orang yang mengakses sistem ini. Kelemahan lain yaitu tidak semua menu tampil di layar saat menggunakan gadget/HP. Saran saat menggunakan sistem ini, gunakan Laptop atau $P C$ dan jaringan yang lebih kuat sehingga komunikasi menjadi lebih lancar dan sistem tetap stabil. Untuk penelitian selanjutnya Schoology akan digunakan sebagai media Blended Learning dan bekerjasama dengan Universitas lain dalam penerapannya.

\section{DAFTAR PUSTAKA}

Aminoto, T., \& Pathoni, H. (2014). Penerapan Media E-Learning Berbasis Schoology Untuk Meningkatkan Aktivitas dan Hasil Belajar Materi Usaha dan Energi Di Kelas XI SMA N 10 Kota Jambi. Jurnal Sainmatika, 8(1), 13-29.

Ardianti, S., Sulisworo, D., \& Pramudya, Y. (2019). Efektivitas Blended Learning Berbasis Pendekatan Stem Education Berbantuan Schoology Untuk Meningkatkan Critical Thinking
Skill Pada Materi Fluida Dinamik. Prosiding Seminar Nasional Pendidikan KALUNI, 2, 240-246. https://doi.org/10.30998/prokaluni. v2i0.67

Bano, M., Zowghi, D., Kearney, M., Schuck, S., \& Aubusson, P. (2018). Mobile learning for science and mathematics school education: A systematic review of empirical evidence. Computers and Education, 121(February 2017), 30-58.

https://doi.org/10.1016/j.compedu. 2018.02.006

Caligaris, M. G., Schivo, M. E., \& Romiti, M. R. (2015). Calculus \& GeoGebra, an Interesting Partnership. Procedia - Social and Behavioral Sciences, 174, 11831188.

https://doi.org/10.1016/j.sbspro.20 15.01 .735

Crompton, H., \& Burke, D. (2018). The use of mobile learning in higher education: A systematic review. Computers and Education, 123, 53-64.

https://doi.org/10.1016/j.compedu. 2018.04.007

Firmansyah, B. H. (2015). Pengembangan Blended Learning berbasis Schoology. Teknologi Pembelajaran, 109(1), 5-10. https://doi.org/10.1017/CBO97811 07415324.004

Haryanto, S. (2018). Kelebihan Dan Kekurangan E-Learning Berbasis Schoology. Prosiding Seminar Nasional Geotik, 2016, 106-110.

Kartika Murni, C. (2016). Pengaruh E- 
DOI: https://doi.org/10.24127/ajpm.v9i3.2790

Learning Berbasis Schoology

Terhadap Peningkatan Hasil

Belajar Siswa Dalam Materi

Perangkat Keras Jaringan Kelas X

Tkj 2 pada SMK Negeri 3

Buduran, Sidoarjo. It-Edu, I(01), 86-90.

Nasrum, A., \& Herlina, H. (2019). Developing of Calculus Teaching Materials Based on Audiovisual. Infinity Journal, 8(2), 209. https://doi.org/10.22460/infinity.v8 i2.p209-218

Purwaningsih, R., Rosidin, U., \& Wahyudi, I. (2017). Pengaruh Penggunaan E-Learing Dengan Schoology Terhadap Hasil Belajar Peserta Didik. Jurnal Pembelajaran Fisika Universitas Lampung, 5(4), 51-61.

Putri, N. W. M. A., Jampel, N., \& Suartama, K. (2014). Pengembangan E-Learning Berbasis Schoology Pada Mata Pelajaran Ipa Kelas Viii Di Smp Negeri 1 Seririt. Jurnal EDUTECH Undiksha, 2(1), 1-11. https://ejournal.undiksha.ac.id/inde x.php/JEU/article/view/3796

Rosalina, M. (2018). Analysis The Use of Schoology E-Learning Towards Students' Learning Motivation Enhancement in STKIP Surya. Indonesian Journal of Science and Education, 2(1), 89. https://doi.org/10.31002/ijose.v2i1. 614

Saputri, O. D., \& Rahmawati. (2019). Peran Guru dalam Memberikan Pelajaran Tambahan (LES) Bagi Peserta Didik Di Luar Jam Pelajaran Sekolah sebagai Wujud
Implementasi Pengabdian Kepada Masyarakat. Prosiding Seminar Nasional Pendidikan Program Pascasarjana Universitas PGRI Palembang, 2, 493-504.

Ulva, N. L., Kantun, S., \& Widodo, J. (2018). Penerapan E-Learning Dengan Media Schoology Untuk Meningkatkan Motivasi Dan Hasil Belajar Siswa Pada Kompetensi Dasar Mendeskripsikan Konsep Badan Usaha Dalam Perekonomian Indonesia. JURNAL PENDIDIKAN EKONOMI: Jurnal Ilmiah Ilmu Pendidikan, Ilmu Ekonomi Dan Ilmu Sosial, 11(2), 96.

https://doi.org/10.19184/jpe.v11i2. 6453

Wahyudi, I. (2017). Pengembangan Program Pembelajaran Fisika SMA Berbasis E-Learning dengan Schoology. Jurnal Ilmiah Pendidikan Fisika Al-Biruni, 6(2), 187.

https://doi.org/10.24042/jipfalbirun i.v6i2.1850 